\title{
Extraction and purification of L-Asparaginase II from local isolate of Proteus vulgaris
}

\author{
Rawaa J. Toma * Asmaa M. Suo'd ** Shahlaa A. Hassan*** \\ Methal A. Abd Aon* Sarab K. Salman*
}

Received 30, May, 2008

Accepted 3, June, 2009

\begin{abstract}
:
Forty one isolates of genus Proteus were collected from 140 clinical specimens such as urine, stool, wound, burn, and ear swabs from patients of both sex. These isolates were identified to three Proteus spp. P. mirabilis, P. vulgaris and $P$. penneri . The ability of these bacteria to produce L-asparaginase II by using semi quantitative and quantitative methods was determined. P. vulgaris Pv.U.92 was distinguished for high level of L-asparaginase II production with specific activity 1.97 U/mg. Optimum conditions for enzyme production were determined; D medium with $0.3 \%$ of L-asparagine at $\mathrm{pH} 7.5$ with temperature degree $35^{\circ} \mathrm{C}$ for incubation.

Ultrasonication was used to destroy the P. vulgaris Pv.U.92 cells then ASNase II was extracted and purified throughout several purification steps including precipitation with $\left(\mathrm{NH}_{4}\right)_{2} \mathrm{SO}_{4}(60-80 \%)$, DEAE-cellulose ion exchanger chromatography followed by Sephacryl S-300 filtration. The specific activity was $155.6 \mathrm{U} / \mathrm{mg}$ and the purification fold was 27.3 with $10.4 \%$ yield.
\end{abstract}

Key words: L-Asparaginase II; $P$. vulgaris; DEAE-cellulose; Sephacryl S-300.

\section{Introduction:}

L-Asparaginase (ASNase) is Lasparagine amido hydrolase enzyme, the systematic code is E.C.3.5.1.1, belongs to an amidase group that produces aspartic acid and ammonia by asparagine hydrolysis $[1,2]$.

L-asparagine $+\mathrm{H} 2 \mathrm{O}=$ L-aspartate + $\mathrm{NH} 3$

L-Asparaginase II (ASNase II) was one of the bacterial extracts that produced by many bacteria, by using the affinity chromatography to purification ASNase from the microorganism, found it's a tetramer with identical subunits[3]. ASNase II is high-affinity enzyme located in the periplasm, which is the space between the inner membrane (cytoplasmic) and outer membrane and only ASNase II[4].

Nearly all of the ASNases produced from the microorganism was the biologically active isozyme[5]. ASNase consider anti-neoplastic drug used in the treatment of cancer such as, lymphoblastic leukaemia chemotherapy [6], melanosarcoma cancers (skin cancers) that causes by Epstein-Barr virus [7], acute lymphocytic leukemia (mainly in children), and lymphosarcoma[8]. ASNase killed the leukemia cells by rapidly depleting L-asparagine, blocking protein synthesis and tumor cell proliferation, especially at G1 phase of the cell cycle [9].

Proteus especially Proteus vulgaris is another bacteria that produce ASNase aerobically with antitumor activity, with molecular weight of LAsparaginase about 120.000 Dalton, the $\mathrm{Km}$ is $2.6 \times 10-5 \mathrm{M}$, the $\mathrm{pI}$ is 5.08 at optimum $\mathrm{pH}$ is 7-8[3].

\footnotetext{
* Ministry of Science and Technology.

** Baghdad University/ collage of Science/ department of Biotechnology.

*** Baghdad University/ collage of Science/ department of Biology
} 
Since, there were no local studies on ASNase II production from P.vulgaris, thus this study was aimed to determined the qualified Proteus isolates for ASNase II production, study several environmental conditions that may affect production of ASNase II, and purification of ASNase II from selected isolate.

\section{Materials and methods:}

A- Enzyme activity: was measured by Indophenol methods [10].

B- Protein concentration: was measured according to Lowery method [11].

C- Media used for production ASNase II:

- Medium A: L-Asparagine broth (salt solution) and L-Asparagine agar[12].

- Medium B (Luria broth) [13]: it mixed with L-asparagine Composition per $100 \mathrm{~mL}$ from Peptone $1 \mathrm{gm}, \mathrm{NaCl} 0.1 \mathrm{gm}$, Yeast extract 0.5 $\mathrm{gm}$, and L-asparagine $0.1 \mathrm{gm}$.

- Media C [13]: Composition per $100 \mathrm{~mL}$ from L-Asparagine 0.1 gm, Peptone 0.5 gm, Yeast extract 0.05 gm, and Glycerol $1 \mathrm{ml}$.

- Media D [14]: Composition per $100 \mathrm{ml}$ (L-Asparagine $0.1 \mathrm{gm}$, Peptone $1 \mathrm{gm}$, and KH2PO4 $0.34 \mathrm{gm}$ ).

- Media E [13]: it was prepared by dissolving $3 \mathrm{gm}$ of nutrient broth, and $0.1 \mathrm{gm}$ L-asparagine in $90 \mathrm{ml}$ of DW, $\mathrm{pH}$ was adjusted to 7.0.

D- Purification of ASNase II: DEAE-cellulose was prepared according to Whitaker and Bernhard [15]. And Sephacryl S-300 column was prepared according to Pharmacia with dimensions $34.2 \times 2.5 \mathrm{~cm}$ and the gel was equilibrated with $0.2 \mathrm{M}$ PPB $\mathrm{pH} 8$.

- Determination of ASNase IIproducing Proteus isolates: after collected 140 clinical specimens and identified the Proteus spp. the ASNase
II producing was determinate by two methods:

a- Semi-quantitative methods: activated isolates on brain heart infusion agar were transferred to the center of L-asparagine agar plate and incubated at $37^{\circ} \mathrm{C}$ for $24-48 \mathrm{hr}$. The control plate was left without inoculation. Appearance of a purple zone around the colony was measured according to the equation below. Also activated isolates were transferred to L-asparagine broth, changing the color of medium to yellow represented a positive result and isolates were selected according to reduced $\mathrm{pH}$ $[16,1]$.

\section{Hydrolysis zone $=$ Diameter of \\ zone/diameter of bacterial colony}

b- Quantity method (Indophenol Method): measurement of ASNase II activity [17] after activated isolates 0.2 $\mathrm{ml}$ of each broth culture growth isolate was transferred to salt L-asparagine medium without phenol red and incubated at $37^{\circ} \mathrm{C}$ for $24 \mathrm{hr}$. then participated by cold centrifuge at 4000 rpm for $30 \mathrm{~min}$. the supernatant was discarded and the pellets were washed twice with $0.2 \mathrm{M}$ PPB buffer $\mathrm{pH} 8$. After that $0.2 \mathrm{ml}$ of each suspension transferred to other new tube and added $0.05 \mathrm{ml}$ of reaction solution of $0.1 \mathrm{M}$ L-asparagine that currently preparation all tubes were incubated in a shaker water bath at $37^{\circ} \mathrm{C}$ for $30 \mathrm{~min}$, The reaction was stopped by adding 5 $\mathrm{mL}$ of (A) indicator and $5 \mathrm{~mL}$ of (B) indicator, with mixing and incubated in water bath at $37^{\circ} \mathrm{C}$ for $20 \mathrm{~min}$. and the O.D was measured at $625 \mathrm{~nm}$, the activity of enzyme was calculated also protein concentration was estimation [11]

- Determination of different conditions on ASNase II production

1) Effect of different media: the activity of enzyme, and protein concentration were measured in each media. 
2) Effect of different concentrations of $\mathbf{L}$-asparagine: the production medium at different concentration of L-asparagine (0.1, $0.2,0.3,0.4,0.5$, and $0.6 \%$ ) after that the activity of enzyme, and protein concentration were measured.

3) Effect of temperature: at different temperatures $(20,25,30,35$, 40 and $45^{\circ} \mathrm{C}$ ) the crude enzyme was incubate after that the cells were precipitated and the activity of enzyme, protein concentration were measured.

4) Effect of pH: Selective medium was prepared at different $\mathrm{pH}$ values $(6,6.5,7,7.5,8,8.5$, and 9$)$, the activity of enzyme and protein concentration were measured.

\section{- $\quad$ Purification of ASNase II}

1) Extraction of enzyme from bacterial cells by Ultrasonication: at different times (2, 4, 8, and $16 \mathrm{~min}$.), the activity of enzyme and protein concentration at each time were measured.

2) Precipitation of enzyme by ammonium sulfate: enzyme was precipitated with different concentration of (NH4)2SO4 (20, 30, $40,50,60,70,80$, and $90 \%$ ) saturation under cooled condition, at each concentration the activity of enzyme, protein concentration and specific activity were measured.

3) Ion exchange chromatography (DEAE-cellulose): The dialyzed enzyme was passed through DEAE-cellulose column, and washed with $0.005 \mathrm{M}$ PPB buffer $\mathrm{pH} 8$ after that the enzyme was eluted with $0.005 \mathrm{M}$ PPB containing certain concentration of $\mathrm{NaCl}$ by stepwise at flow rate $0.05 \mathrm{~mL} / 8 \mathrm{sec}$. $(22.2 \mathrm{~mL} / \mathrm{I} \mathrm{hr})$.

4) Gel filtration by Sephacryl S300: The concentrated enzyme solution was applied to the column of Sephacryl S-300 at flow rate was $0.05 \mathrm{ml} / 30 \mathrm{sec}$, enzyme activity was measured in the peak fractions and the active fractions were collected, volume, protein and enzyme activity were measured. Specific activity, yield $\%$, and fold purification were calculated in each purification step.

\section{Result and Discussion:}

1- Screening for L-asparaginase II producing by Proteus spp.: by Semiquantitative screening methods: it's simple and rapid assay method for the detection of ASNase from different strain of bacteria $[16,1]$.

- Screening on solid media: Table (1) showed that Proteus species were able to produce ASNase II but with differences in their quantities, the ability of isolates to produce ASNase II was ranged between 4 to $27 \mathrm{~mm}$. Notable $P$. vulgaris isolates were appeared to be the most efficient isolates to produce this enzyme (ASNase II).

- Screening in broth media: The ability of Proteus species to produce ASNase II in broth medium was determined according to the changing of the $\mathrm{pH}$ value (table 2). The average of final $\mathrm{pH}$ value was ranged from 6.9-8.6. Furthermore, it can be noticed that $P$. vulgaris isolates were the more efficient to produce ASNase II, followed by $P$. mirabilis. This result was corresponded to previous study that referred to the ability of Enterobacteriaceae for production ASNase II [18]. Because the $P$. vulgaris was more able to utilize the medium compound or they were had multiple ans $B$ genes (that code for ASNase II production) in their genome to produce this enzyme in higher level [19] compared with other Proteus spp.. Therefore Proteus spp. isolates that recorded average $\mathrm{pH}$ value up to 8 were selected for quantitative detection of ASNase II production. 
2- Quantitatively screening (Indophenol method) for ASNase II production: Table (3) indicated the quantitative activity of enzyme for 12 selected isolates of Proteus spp. It was revealed that isolate $P$. vulgaris Pv.U.92 had the highest activity of ASNase II. Thus P. vulgaris Pv.U.92 was selected for further study.

3- Effect of environmental factors on production of ASNase II by $P$. vulgaris Pv.U.92:

- Effect of media compounds: Figure

(1) illustrated that D medium was the best one for production enzyme; this medium was enhanced enzyme production.

- Notable, El-Bessoumy and his team was recommended for using similar medium for enhances production of ASNase II by Pseudomonas aeruginosa 50071 bacteria [20]. Obviously, the type of carbon, nitrogen source as well as culture condition of media were affected the level of ASNase II production [21] by effected on microorganism growth or on enzyme united with substrate.

Table (1): ASNase II produced by Proteus species on solid medium

\begin{tabular}{|c|c|c|c|}
\hline $\begin{array}{l}\text { Proteus } \\
\text { isolates }\end{array}$ & $\begin{array}{l}\text { Diameter of } \\
\text { asparagine } \\
\text { hydrolysis } \\
\text { zone }(\mathbf{m m})\end{array}$ & $\begin{array}{l}\text { Proteus } \\
\text { isolates }\end{array}$ & $\begin{array}{l}\text { Diameter of } \\
\text { asparagine } \\
\text { hydrolysis } \\
\text { zone }(\mathbf{m m})\end{array}$ \\
\hline Pm.W.01 & 13 & Pm.U.77 & 16 \\
\hline Pp.S.06 & 22.9 & Pm.B.82 & 23 \\
\hline Pm.U.14 & 6 & Pp.S.85 & 13 \\
\hline Pm.U.15 & 20 & Pv.U.88 & 22 \\
\hline Pm.U.16 & 22 & Pm.U.89 & 13 \\
\hline Pm.U.19 & 26.5 & Pm.W.90 & 25 \\
\hline Pm.U.20 & 7 & Pv.U.92 & 27 \\
\hline Pm.W.23 & 25 & Pm.U.95 & 11 \\
\hline Pm.W.24 & 22.5 & Pp.U.98 & 20 \\
\hline Pm.B.25 & 1.5 & Pp.W.100 & 24 \\
\hline Pm.U.30 & 7 & Pm.U.103 & 23 \\
\hline Pm.U.32 & 21 & Pm.E.108 & 25 \\
\hline Pv.U.34 & 25 & Pm.U.115 & 9 \\
\hline Pm.U.35 & 16 & Pm.W.120 & 12 \\
\hline Pv.E.50 & 26 & Pm.W.125 & 5 \\
\hline Pm.U.56 & 18 & Pm.W.130 & 4 \\
\hline Pm.E.67 & 18 & Pv.W.133 & 22 \\
\hline Pv.E.68 & 24 & Pm.E.135 & 10 \\
\hline Pm.S.70 & 21 & Pm.U.137 & 8 \\
\hline Pv.U.72 & 27 & Pv.U.140 & 14 \\
\hline Pm.U.73 & 22 & Control & 0 \\
\hline \multicolumn{2}{|c|}{$\begin{array}{l}\text {-The result represent average } \\
\text { of duplicate reading } \\
-\mathrm{Pm}=\boldsymbol{P} \text {. mirabilis, } \\
-\mathrm{Pv}=\boldsymbol{P} \text {. vulgaris } \\
\text { - } \mathrm{Pp}=\boldsymbol{P} \text {. penneri }\end{array}$} & \multicolumn{2}{|c|}{$\begin{array}{l}\text { - } \mathrm{E}=\text { ear swabs } \\
\text { - } \mathrm{U}=\text { urine sample } \\
\text { - } \mathrm{S}=\text { stool sample } \\
\text { - } \mathrm{W}=\text { wound swab }\end{array}$} \\
\hline
\end{tabular}

Table (2) ASNase II produced by Proteus species in broth medium according to $\mathrm{pH}$ value

\begin{tabular}{|c|c|c|c|}
\hline $\begin{array}{c}\text { Proteus } \\
\text { isolates }\end{array}$ & $\begin{array}{c}\text { pH } \\
\text { value }\end{array}$ & $\begin{array}{c}\text { Proteus } \\
\text { isolates }\end{array}$ & $\begin{array}{c}\text { pH } \\
\text { value }\end{array}$ \\
\hline Pm.W.01 & 7.1 & Pm.B.82 & 7.6 \\
\hline Pp.S.06 & 7.4 & Pp.S.85 & 7.2 \\
\hline Pm.U.14 & 7.0 & Pv.U.88 & $\mathbf{8 . 2}$ \\
\hline Pm.U.15 & 7.2 & Pm.U.89 & 7.0 \\
\hline Pm.U.16 & 7.7 & Pm.W.90 & 7.7 \\
\hline Pm.U.19 & 7.9 & Pv.U.92 & $\mathbf{8 . 5}$ \\
\hline Pm.U.20 & 7.0 & Pm.U.95 & 7.4 \\
\hline Pm.W.23 & 7.2 & Pp.U.98 & 7.5 \\
\hline Pm.W.24 & 7.6 & Pp.W.100 & $\mathbf{8 . 0}$ \\
\hline Pm.B.25 & 7.3 & Pm.U.103 & $\mathbf{8 . 6}$ \\
\hline Pm.U.30 & 7.5 & Pm.E.108 & $\mathbf{8 . 4}$ \\
\hline Pm.U.32 & 7.4 & Pm.U.115 & 7.0 \\
\hline Pv.U.34 & $\mathbf{8 . 3}$ & Pm.W.120 & 7.2 \\
\hline Pm.U.35 & 7.0 & Pm.W.125 & $\mathbf{8 . 4}$ \\
\hline Pv.E.50 & 7.9 & Pm.W.130 & 6.9 \\
\hline Pm.U.56 & 7.2 & Pv.W.133 & $\mathbf{8 . 0}$ \\
\hline Pm.E.67 & 7.4 & Pm.E.135 & 7.1 \\
\hline Pv.E.68 & $\mathbf{8 . 5}$ & Pm.U.137 & 7.3 \\
\hline Pm.S.70 & 7.8 & Pv.U.140 & $\mathbf{8 . 6}$ \\
\hline Pv.U.72 & $\mathbf{8 . 3}$ & Control & 6.9 \\
\hline Pm.U.73 & $\mathbf{8 . 1}$ & & \\
\hline Pm.U.77 & 7.8 & & \\
\hline The result represent average of duplicate reading \\
\hline
\end{tabular}

Table (3) Activity of ASNase II production by Proteus species by using quantitative method

\begin{tabular}{|c|c|c|c|}
\hline $\begin{array}{c}\text { Proteus } \\
\text { isolates }\end{array}$ & $\begin{array}{c}\text { Activity of } \\
\text { ASNase II } \\
\text { (U/ml) }\end{array}$ & $\begin{array}{c}\text { Concentration } \\
\text { of protein } \\
\text { (mg/ml) }\end{array}$ & $\begin{array}{c}\text { Specific } \\
\text { activity } \\
\text { (U/mg) }\end{array}$ \\
\hline Pv.U.34 & 4.4 & 3.9 & 1.13 \\
\hline Pv.E.68 & 7.1 & 4.63 & 1.50 \\
\hline Pv.U.72 & 3.1 & 2.5 & 1.24 \\
\hline Pm.U.73 & 5.8 & 3.65 & 1.59 \\
\hline Pv.U.88 & 6.4 & 4.3 & 1.49 \\
\hline Pv.U.92 & $\mathbf{6 . 6 7}$ & $\mathbf{3 . 3 8}$ & $\mathbf{1 . 9 7}$ \\
\hline Pp.W.100 & 5.8 & 3.5 & 1.66 \\
\hline Pm.U.103 & 3.3 & 2.5 & 1.32 \\
\hline Pm.E.108 & 5.6 & 3.1 & 1.81 \\
\hline Pm.W.125 & 6.6 & 4.7 & 1.40 \\
\hline Pv.W.133 & 1.5 & 2 & 0.75 \\
\hline Pv.U.140 & 7.3 & 4.5 & 1.62 \\
\hline
\end{tabular}

- The result represent average of duplicate reading

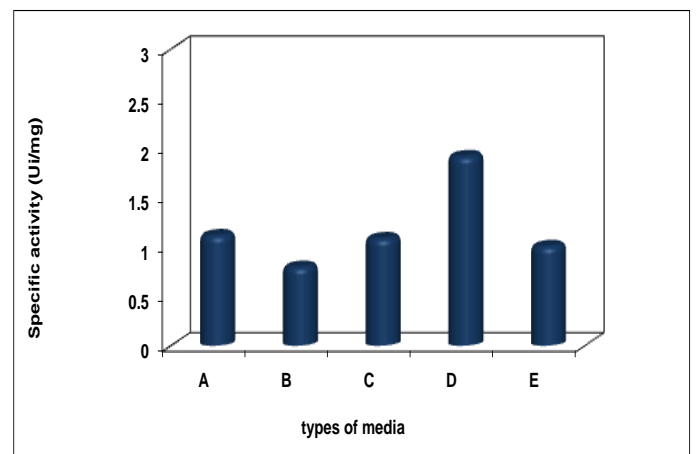

Fig.(1) effect of media on ASNase II production by $P$. vulgaris Pv.U.92 (at pH 7.0 in $37^{\circ} \mathrm{C}$ for $24 \mathrm{hr}$.) 
- Effect of L-asparagine concentration: Figure

indicated that the specific activity of ASNase II produced by $P$. vulgaris Pv.U.92 was increased gradually by addition of Lasparagine to $\mathrm{D}$ medium until it reached $1.8 \mathrm{U} / \mathrm{mg}$ at $0.3 \mathrm{gm}$ of $\mathrm{L}-$ asparagine. This amino acid (Lasparagine) was enhanced the bacterial growth and produced ASNase II [22]. The substrate affinity of L-asparaginase II for Lasparagine is related to its degree of effectiveness against(1).

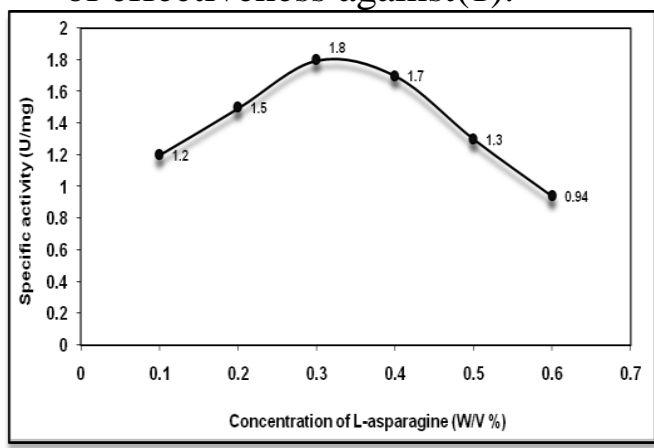

Fig.(2) Effect of L-asparagine concentrations on ASNase II production from P. vulgaris Pv.U.92 (at pH 7.0 in $37^{\circ} \mathrm{C}$ for $24 \mathrm{hr}$.)

- Effect of pH: The specific activity of ASNase II produced by $P$. vulgaris Pv.U.92 was increased at $\mathrm{pH} 7.5$, then as shown in figure (3) this referred to produce the ASNase II approximately was in medium tend to equal and alkaline $\mathrm{pH}$. It can conclude that $P$. vulgaris produced ammonia when growth in medium this increased $\mathrm{pH}$ of medium therefore it enhanced to produced this enzyme. The optimum $\mathrm{pH}$ was found to be 7.5 for ASNase II in Marine actinomycetes which is close to blood $\mathrm{pH}$ [1], compared to Lasparaginases from other bacterial sourcessuch as Serratia marcescens, Mycobacterium spp. and Pseudomonas spp showed optimum $\mathrm{pH}$ in the range of 8.0 to
8.5 [1], while Tosa and the others [23] referred to the optimum $\mathrm{pH}$ of $P$. vulgaris OUT8226 for production ASNase II was 7.0. $\mathrm{pH}$ value may change during the incubation time as a result to bacterial metabolism processes; this also differed according to bacterial strain, nature of enzyme and components of media. $\mathrm{pH}$ effect on ASNase II activity by ionization free enzyme or on enzyme-substrate complex [24].

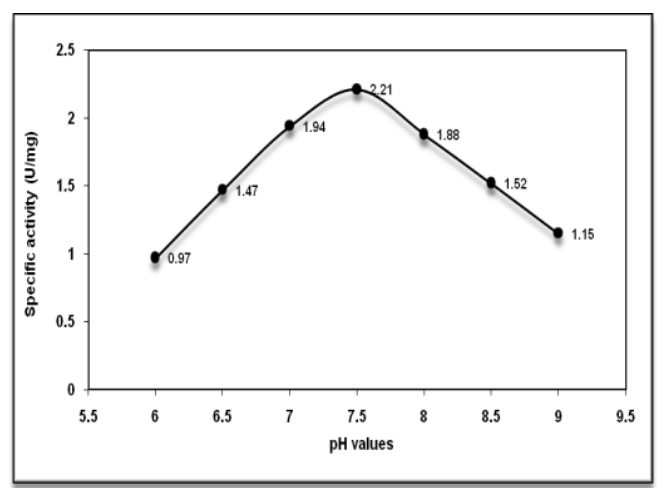

Fig.(3) Effect of pH on ASNase II production from $P$. vulgaris Pv.U.92 (at $37^{\circ} \mathrm{C}$ for $24 \mathrm{hr}$.)

- Effect of temperature: Figure (4) showed that the specific activity of ASNase II produced by $P$. vulgaris Pv.U.92 cultivated in D medium was increased gradually by increasing the temperature of incubation, thus it was noticed that incubation of culture at $35^{\circ} \mathrm{C}$ enhancing the specific activity of ASNase II for production to 1.62 $\mathrm{U} / \mathrm{mg}$. The temperature it effect on stability of enzyme and on solubility the substrate also on ionization enzyme -substrate complex [24, 25]. 


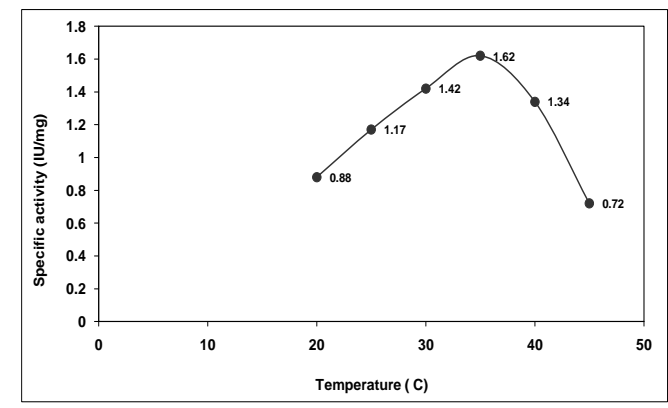

Fig.(4) Effect of temperature on ASNase II production from $P$. vulgaris Pv.U.92 (at pH 7.5 for $24 \mathrm{hr}$ )

4- Extraction of ASNase II by Ultrasonication from $P$. vulgaris Pv.U.92 cells: Cells of $P$. vulgaris Pv.U.92 cultivated in $\mathrm{D}$ medium at $\mathrm{pH}$ 7.5 and temperature $35^{\circ} \mathrm{C}$ were exposed to Ultrasonicator at different times. Figure (5) demonstrated that the specific activity of ASNase II was increased $(2.13 \mathrm{U} / \mathrm{mg})$ when cells of this isolate were disrupted for $4 \mathrm{~min}$, and at this time about $90.3 \%$ of ASNase II was released from the cells, and the prolonged time was effect on the tetramer protein structure of this enzyme

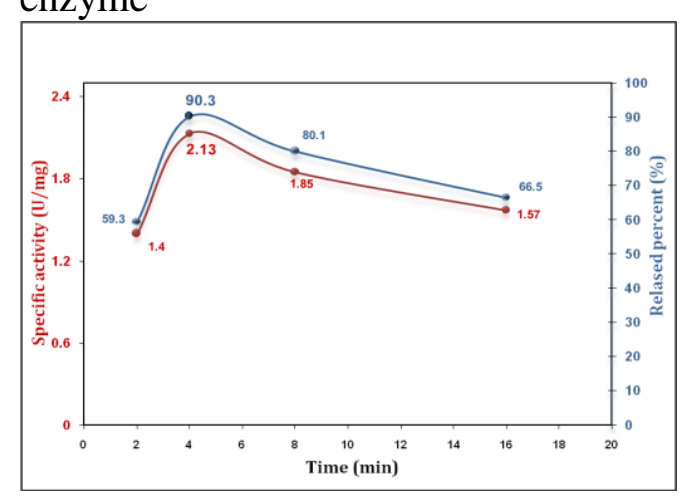

Fig. (5) Specific activity and released percent of ASNase II production from $P$. vulgaris Pv.U.92 at different times of Ultrasonication

\section{5- Purification of ASNase II} produced by $P$. vulgaris Pv.U.92: It was included three steps:

-Precipitation by Ammonium sulfate $\left(\mathbf{N H}_{4}\right)_{2} \mathbf{S O}_{4}:$ It was observed that the specific activity of ASNase II was increased gradually with increasing $\left(\mathrm{NH}_{4}\right)_{2} \mathrm{SO}_{4}$ concentrations and it would be $2.2 \mathrm{U} / \mathrm{mg}$ at $70 \%$ of
$\left(\mathrm{NH}_{4}\right)_{2} \mathrm{SO}_{4}$ (figure 6). Ammonium sulfate was used because it has higher soluble ability, easy to use and its cheap [27], also $\left(\mathrm{NH}_{4}\right)_{2} \mathrm{SO}_{4}$ act to equal the charge on protein surface therefore the ASNase II became insoluble and precipitated ${ }^{[28]}$. Notable, Basha and the other observed similar result when worked on Marine actinomycetes [1].

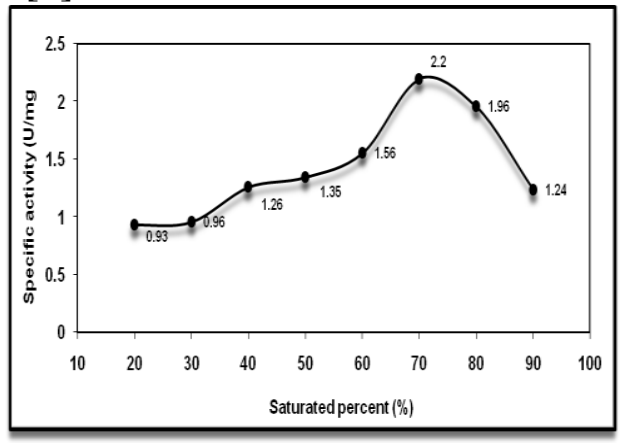

Fig.(6) Precipitation of ASNase II produced by $P$. vulgaris Pv.U.92 with different concentrations of $\left(\mathrm{NH}_{4}\right)_{2} \mathrm{SO}_{4}$

- Purification ASNase II by DEAE-cellulose ion exchange chromatography: The result in figure (7) revealed 3 peaks in washing fraction and 7 peaks in eluted fraction. The activity of enzyme was measured at each eluted peak. Only three peaks were displayed enzyme activity at eluted fraction. Peak number 2 showed the maximum specific activity (table 4), it was $20 \mathrm{U} / \mathrm{mg}$ in comparison with others. This result may suggest that ASNase II produced by $P$. vulgaris Pv.U.92 had negative charge. From this result, it can be considered that ASNase II has many forms (isoenzyme) because it revealed multiple activity peaks. However, almost bacteria belonged to Enterobacteriaceae family have isoforms for this enzyme [4] such as E. coli [29] and pseudomonas aeroginosia [20].

- Isoforms of any enzyme had approximately the same molecular 
weight but they differ in isoelectric point (pI) which makes their separation impossible by gel filtration, because they have small differences in charging properties resulting from altered amino acid composition. Thus ion-exchange chromatography can use for separation isoenzymes ${ }^{[30]}$.

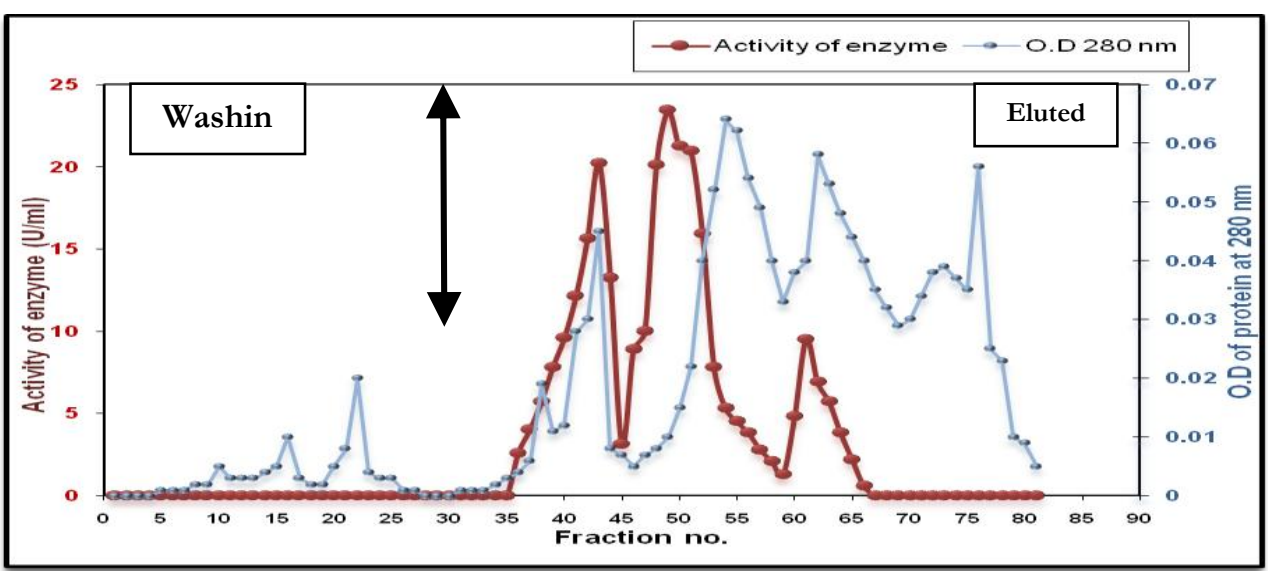

Fig. (7) DEAE-cellulose ion exchange to purified ASNase II from P. vulgaris Pv.U.92 with collection volume $(3 \mathrm{ml})$ at flow rate $22.2 \mathrm{~mL} / 1 \mathrm{hr}$

Table (4) purification schedule of Ion exchange peaks

\begin{tabular}{|c|c|c|c|c|c|c|c|}
\hline $\begin{array}{c}\text { No. } \\
\text { of } \\
\text { peak }\end{array}$ & $\begin{array}{c}\text { Volume } \\
(\mathbf{m l})\end{array}$ & $\begin{array}{c}\text { Activity } \\
\text { of enzyme } \\
(\mathbf{U} / \mathbf{m l})\end{array}$ & $\begin{array}{c}\text { Concentration } \\
\text { of protein } \\
(\mathbf{m g} / \mathbf{m l})\end{array}$ & $\begin{array}{c}\text { Specific } \\
\text { activity } \\
(\mathbf{U} / \mathbf{m g})\end{array}$ & $\begin{array}{c}\text { Total } \\
\text { activity } \\
(\mathbf{U} / \mathbf{m l})\end{array}$ & $\begin{array}{c}\text { Yield } \\
(\boldsymbol{\%})\end{array}$ & $\begin{array}{c}\text { Fold } \\
\text { purification }\end{array}$ \\
\hline 1 & 12 & 7.56 & 0.32 & 23.6 & 90.7 & 9.7 & 4.1 \\
\hline 2 & 15 & 20 & 0.4 & 50 & 300 & 31.9 & 8.8 \\
\hline 3 & 15 & 5.8 & 0.63 & 9.2 & 87 & 9.3 & 1.6 \\
\hline
\end{tabular}

- Purification of ASNase II by Sephacryl S- 300 gel chromatography: Fraction tubes that represented peak 2 were selected for purification by gel filtration chromatography. Firstly, fractions were concentrated by sucrose, and then specific activity of ASNase II was measured and then gel filtration step was applied. Results in table (5) showed the increasing of specific activity of this enzyme. Subsequently, the concentrated enzyme was purified by Sephacryl S-300 column. Figure (8) demonstrated 3 peaks at optical density 280nm. The specific activity of each peak was estimated. Only one peak had enzyme activity. It was $155.6 \mathrm{U} / \mathrm{mg}$ with $10.4 \%$ yield and 27.3 fold of purification. In general, the differences in the specific activity of ASNase II may return to the concentration of proteins or kind of purification materials (gel) as well as type of methods that used for purification [20,30]. Sephacryl S 300 it's suitable for fast run (short run times), high recovery separations at laboratory and industrial scale ${ }^{[30]}$. 
Table (5) purification schedule for ASNase II purification

\begin{tabular}{|c|c|c|c|c|c|c|c|}
\hline 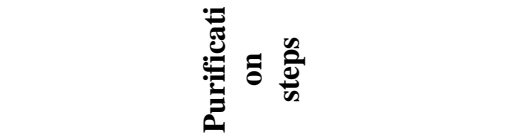 & $\begin{array}{l}\text { छ } \\
\dot{0} \\
\dot{0}\end{array}$ & 至 & 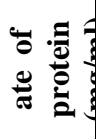 & 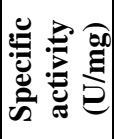 & 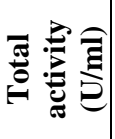 & $\stackrel{ }{0}$ & 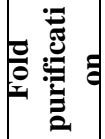 \\
\hline Crude enzyme & 40 & 23.5 & 4.1 & 5.7 & 940 & 100 & 1 \\
\hline $\begin{array}{c}\text { Precipitate with }\left(\mathrm{NH}_{4}\right)_{2} \mathrm{SO}_{4}(60-80 \%) \\
\text { (after dialysis) }\end{array}$ & 18 & 35.8 & 2.3 & 15.6 & 644.4 & 68.6 & 2.7 \\
\hline DEAE-cellulose column & 15 & 20 & 0.4 & 50 & 300 & 31.9 & 8.6 \\
\hline Concentrate with sucrose & 8 & 26.4 & 0.4 & 66 & 211.2 & 22.5 & 11.6 \\
\hline Sephacryl S-300 column & 7 & 14 & 0.09 & 155.6 & 98 & 10.4 & 27.3 \\
\hline
\end{tabular}

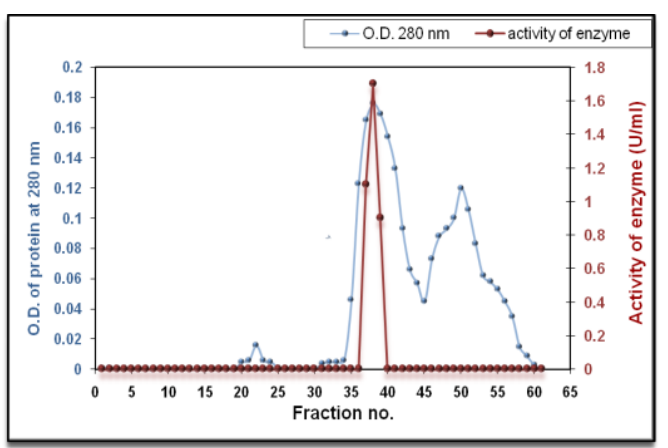

Fig.(8): Gel filtration of ASNase II produced by $P$. vulgaris Pv.U.92 by Sephacryl-S 300 column with volume of fraction was $(3 \mathrm{ml})$ at flow rate $0.7 \mathrm{ml} / \mathrm{min}$

\section{References:}

1. Basha, N. S.; Rekha, R.; Komala, M.; and Ruby, S. 2009. Production of Extracellular Anti-leukaemic Enzyme Lasparaginase from Marine Actinomycetes by Solidstate and Submerged Fermentation: Purification and Characterisation. Tropical J. of Pharm.Res., vol.8 (4): 353-360

2. Capizzi,R.L; Poole, M.; Cooper, M.P.; Richards, F.; Stuart, J.J.; Jakson, D.V.; White,D.R.; Spurr, C.L.; Hopkins, J.O.; and Muss, H.B. 1984. Treatment of poor risk acute leukemia with sequential higdone ARA-C and asparaginase. Blood. 63:649-700.

3. Wriston, J.C.1985. L-Asparagine amidohydrolase. In: Meister, A.(ed.) Methods in enzymology, volume 113. Academic Press,Inc.

4. Campbell,H.A.; Mashburn,L.T.; Boyse,E.A.; and Old, L.J. .1967. Two L-asparaginase from
Escherichia coli B. Their separation, purification, and antitumor activity. Bioche. 6:721730.

5. Roberts,J.; Burson,G.; and Hill,J.M. 1968. New procedures for purification of L-Asparaginase with high yield from E. coli. J. Bacteriol.. 95(6):2117-2123.

6. Keating, M.J.; Holmes,R.; Lerner,S.; and Ho,D.H. 1993. Lasparaginase and PEG asparaginase - Past, present and future. Leuk. Lymphoma. 10: 153-157.

7. Obama, K.; Tara,M.; and Nina,K. 1999. L-asparaginase induced complete remession in EpsteinBarr virus, positive, multidrug resistant, cutaneous T-cell lymphoma. Int.J.Hematol. 69:260262.

8. Soares,A.L.; Guimaraes, G.M.; Polakiewicz, B.; de Moraes Pitombo, R.N.; and Abrahao-Neto, J. 2002. Effects of polyethylene glycol attachement on physicochemical and biological stability of E. coli L-asparaginase. Intern. J. of pharma.. vol. 237:163170.

9. Appel, I.M.; den Boer, M.L.; Meijerink, J.P.; Veerman,A.J.; Reniers, N.C.; Pieters, and R. 2006. Up-regulation of asparagine synthetase expression is not linked to the clinical response Lasparaginase in pediatric acute lymphoblastic leukemia. Blood. 107(11):4244-4249. 
10. Weatherburn, M. W., 1967. Phenol-hypochlorite reaction determination of ammonia. Anal. Chem. 39(8):971-974.

11. Lowry, 0. H.; Rosebrough,N. J.; Farr,A. L.; and Randall, R. J. 1951. Protein measurement with the Folin phenol reagent. J. Biol. Chem. Vol.193:265-275.

12. Beck, J. V. 1971. Enrichment culture and isolation techniques particularly for aerobic bacteria. In: Jakoboy, W. B. (ed.) Methods in enzymology. vol. 22:46-61. Academic press, New York.

13. Sukumaran,C.P.; Singh,D.V.; and Mahadevan,P.R. 1979. Synthesis of L-asparaginase by Serratia marcescens. J.Biosci. 1(3):263269.

14. Bilimoria,M.H. 1969. Conditions for the production of L.asparaginase II by coliform bacteria. Appl. Microbiol. 18(6):1025-1030.

15. Whitaker, J. R.; and Bernard,R.A. 1972. Experiments for an Introduction of Enzymology the Wibber press. Davis.

16. Gulati, R.; Saxena,R.K.; and Gupta,R. 1997. A rapid plate assay for screening L-asparaginase producing microorganisms. Lett. Appl. Microbiol.vol. 24: 23-26.

17. Novak,E.K.; and Phillips,A.W. 1974. L-glutamine as a substructure for L-asparaginase from Serratia marcescens. J. Bact. Vol.117(5):593-600.

18. Imada, A.; Igarasi,S.; Nakahoma K.; and Isona,M. 1973. Asparaginase and glutaminase activities of microorganism. J. Gen. Microbiol. vol. 76:85-99.

19. Wade,H.E.; Robinson,H.K.; and Phillips,B.W. 1971. The asparaginase activity of bacteria. J.Gen.Microbiol. vol.65.

20. El-Bessoumy, A. A.; Sarhan,M. and Mansour,J. 2004. Production,
Isolation, and Purification of LAsparaginase from Pseudomonas Aeruginosa 50071 Using Solidstate Fermentation. J. Biochem. and Molecular Bio., 37(4): 387393.

21. Saad, M.R. 1990. Principles in Microbial physiology, higher education ministry, Mosel, Iraq (in Arabic).

22. Clark,P.H. 1980. The utilization of amides by microorganism. In: Payne J.W. (ed.) Microorganism and nitrogen sources. John Wiley and sons. New York. 563-576.

23. Tosa,T; Sano,R.; Yamamoto,K.; Nakamura, M.; Ando,K.; and Chibata,I. 1971. L-Asparaginase from Proteus vulgaris. Amer. Soci. for Microbio. 22(3): 387-392.

24. Mokrane,S.A. 2003. Production, Purification, and Characterization of L-Asparaginase II from a local isolate of E.coli. College of science / Baghdad University. Iraq (thesis).

25. Pritsa, A.A.; Papazisis,K.T.; Kortsaris, A.H.; and Geromichalos, G.D. 2001 .Antitumor activity of L-asparaginase from Thermus thermophilus. Anti. Drugs. 12(2):137-142.

26. Uhlig,H. $1998 . \quad$ Industrial enzymes and their applications. John Wiley and sons. Inc. New York.

27. Voleskey,B.; and Luong,L. 1985. Microbiol enzyme: production, purification and isolation. CRC. Biotecnology. Vol. 2:119-146.

28. White,A.; Handler, P.; and Smith,E. 1972. Principle of Biochemistry. M.C. Grow Hill Book Company. A blakiston publishing. New York.

29. Jennings, M. P.; and Beacham,I. R. 1990. Analysis of the Escherichia coli gene encoding Lasparaginase II, ansB, and its regulation by cyclic AMP receptor 
and FNR proteins. J. Bacteriol. 172(3): 1491-1498.

30. AL-Azawi, M.A.H. 2005.

Production and Purification of L-

Asparaginase II from a local isolate of Serratia marcescens. College of science / Baghdad University. Iraq (Thesis).

\section{استخلاص وتنقية أنزيم L-Asparaginase II المنتج مـن بكتريـا Proteus vulgaris}

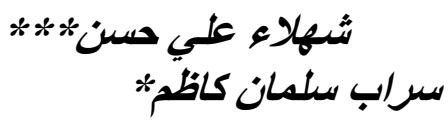

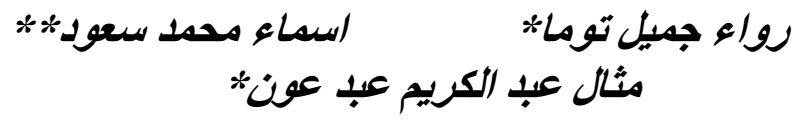

*وزارة العلوم و التكنولوجيا.

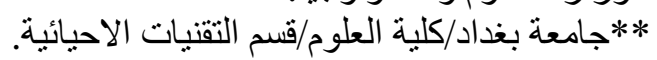

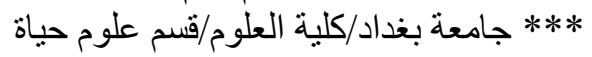

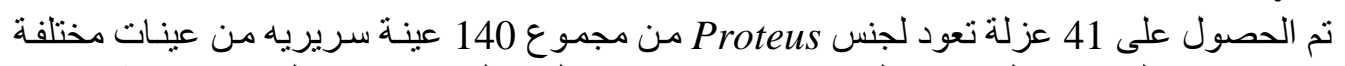

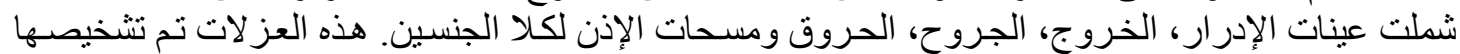

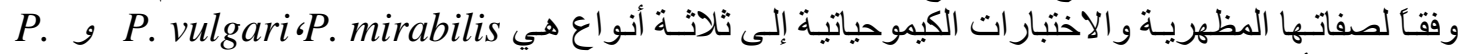
penneri

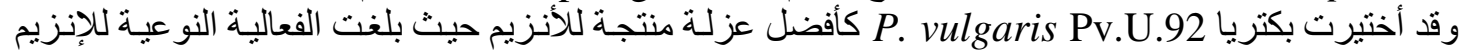

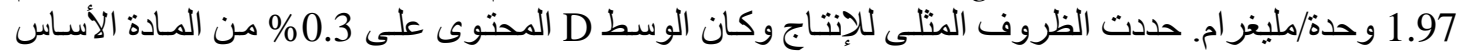

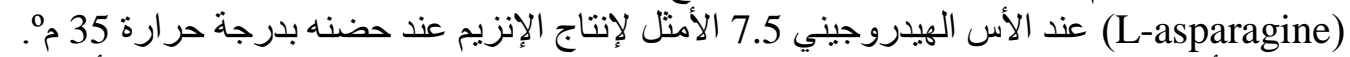

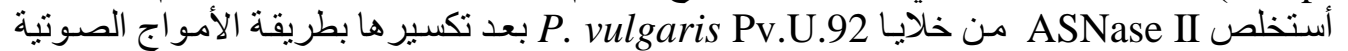

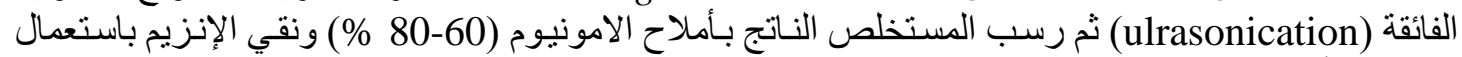

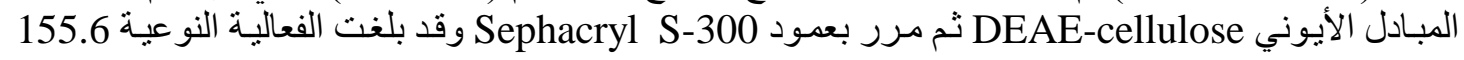
وحدة/مل غرام وبمحصلة إنزيمية 10.4 \% وبعدد مر ات التنقية 27.3 . 